\title{
Informal Practices in Public Administrations in \\ Cameroon
}

\author{
Michael TAOYANG WARAI \\ Lecturer/Researcher \\ $\mathrm{PhD}$ in Political Science \\ (Faculty of Law and Political Science/ University of Ngaoundéré, Cameroon) \\ Department of Political Science \\ E-mail: mtaoyangwarai@gmail.com
}

Received: Nov. 24, 2020 Accepted: Dec. 21, 2020 Online published: Jan. 15, 2021

doi:10.5296/jpag.v11i1.17986ＵRL: https://doi.org/10.5296/jpag.v11i1.17986

\begin{abstract}
The article questions the practices of violation of the law and the link between illegality and administrative practices, with a focus on administrative services. In this paper, I propose to study the experience of Cameroon, a country where formality and informality work hand in hand. Precisely, administrative practices have for some time seen the proliferation of unconventional practices in the management of administrative services. The assessment is the use of informality that rub shoulders with the formal rules established by the legislator. The informal management of administrative services can be explained on the one hand by the state crisis which results in the state registry struggling to take. Administrative burdens as an institutional factor should not also be overlooked as an explanatory factor for this practice. Informality, therefore, becomes an alternative to bypass regulatory frameworks. The objective of this article is to stimulate reflection on the role that informality can play in administrative practices in Cameroon. Starting from the principle of methodological individualism, we demonstrate that informality is a vector of underdevelopment, and this way of doing must retain the attention of governments to overcome this practice.
\end{abstract}

Keywords: informality, public administrations, service, corruption

\section{Introduction}

The Cameroonian administrative services from empirical evidences have been experiencing some crisis linked to the intrusion of obnoxious practices in its processes for several decades. This crisis is an informality that has invaded almost all the administrative services of the 
country. According to Lautier et al. (1991: 6), "it is in the relationship to the state that we always find the center of the definition of informality". A reflection on these unconventional practices represents for us as a researcher a path of investigation to find out a scientific explanation to it. First, the term (informal) refers to a situation that is "not formal or official", Cambridge Advanced Dictionary, $4^{\text {th }}$ Edition (2015:800). In practice, formality and informality always coexist in our different administrations. To confirm this matter, empirical evidences proved that most of the services offered to individuals operate on a daily basis thanks to various negotiations done out of formal or legal standards. Fundamentally, modern organizations rely heavily on formal structures, with formal rules that organize them and structure individual actions. Today, the Cameroonian public services are infested with the practices of informality, including those that operate and are carried out within and around formal institutions. It is trivial to observe that each formal rule is accompanied by its peer, informality. It is therefore evident that this dialectic is full of practical consequences, which make informality an interesting subject to study. Since it is practiced within the public administration, which has the basic mission of protecting public resources and executing decisions on behalf of the state, it has in principle a set of measures aimed at creating an environment that promotes ethics, accountability, and transparency. The mission of administrations is fundamentally to implement good governance policies in public services.

Administration as an organization is, "a body of individuals working under a defined system of rules, assignments procedures, and relationships designed to achieve identifiable objectives and goals." Greenwald, H. P. (2008). According to Edgard Schein, an "organization is a complex social structure which must be studied as a whole system to fully understand the individual behavior of its members" (Shein, 1971: 456). It is also "the accomplishment of an objective that requires a collective effort, men set up an organization designed to coordinate the activities of many persons and to furnish incentives for others to join them for this purpose." (Blau, P. M., \& al., 1962: 5). This implies that the action of an organization is daily. Any responsibility will therefore imply the establishment of instituted structures and procedures, as well as the definition of responsibilities and means necessary for the accomplishment of the missions of public service. Social realities most often affect the internal set up of some organizations. As a social unit made up of groups of individuals an organization as can as well be considered as:

"a social unit of people, systematically structured and managed to meet a need or to pursue collective goals on a continuing basis. All organizations have a management structure that determines relationships between functions and positions, and subdivides and delegates roles, responsibilities, and authority to carry out defined tasks. Organizations are open systems in that they affect and are affected by the environment beyond their boundaries."

Unfortunately, from facts and daily observations, the administration through its bureaucracy in Cameroon is experiencing the intrusion of perverse (unethical) practices that prevail in the relations between the administration, citizens and users. Informality unfolds according to a

\footnotetext{
${ }_{1}^{1}$ http://www.businessdictionary.com/definition/organization.html. Retrieved March 18, 2012, from BusinessDictionary.com
} 
hierarchy of actors and is constructed by chains of social relationships, generally supported by personal, family, ethnic, cultural and/or religious ties. These practices consist in practicing traffic of influence in the processing of cases or even the use of individuals or middlemen trivially called in French "démarcheurs". This practice is called "informality" in the sociology of organizations and administrative science. The concept of informality has several meanings, "despite the polysemy of this notion in the theory of organizations, the informal is always set up in opposition to its enemy brother: the formal" (Geoffroy, 2014: 9). This is an evidence that will confirm the fact that as far as formalities exist, informalities will always be around as a pair.

Besides, it is important to clarify some concepts. The term informality is a qualifier that designates the unofficial, irregular and non-formal. Experienced on daily basis in administrative services, informality corresponds to "spontaneous and flexible links established between the members of the organization on the basis of feelings and personal interests essential to the functioning of the formal part of the organization ...", in contrast, the formal is "that which is planned and which is the object of an agreement" (Dalton, 1959: 219.). As public administrative policies are closely linked to governance, informality will also imply informal governance which is defined as "those non-codified settings of day-to-day interaction concerning policy issues, in which the participation of actors, the formation of coalitions, the processes of agenda setting, (preliminary) decision-making and implementation are not structured by pre-given sets of rules or formal institutions" (Van Tatenhove et al., 2006: 14). The informal therefore involves all administrative practices that do not respect the rules or standards established by law, "the informal covers three types of behavior: first, those which are not planned or formally structured come more or less spontaneously from needs of individuals; second, those which take place alongside the formal and finally those which oppose the formal" (Litterer, 1963: 13). All behavior not foreseen by the legal authority therefore falls under the aegis of the informal. As far as the formal is concerned, the Hachette dictionary (2010: 632) defines it as anything "which is clearly determined, which cannot be discussed".

Generally, the Cameroonian State operates with legal rules established by the legislator, with regard to the management of administrative services. According to the law, a civil servant is bound according to:

"Article 36. Which states that: (1) The civil servant is required to personally provide the public service to be entrusted to him and to devote in all circumstances with diligence, probity, respect for the public good and sense of responsibility

(2) He is also required to respond to requests for information from the public, either from his own initiative, or to meet user demand, in compliance with the rules relating to the obligations of discretion and professional discretion provided for in Articles 40 and 41 of this decree",

\footnotetext{
${ }^{2}$ Decree $N^{\circ}$ 94/199 of 07 October 1994 on General Status of the Public Service of the State Amended and Completed by Decree ${ }^{\circ} 2000 / 287$ of 12 October 2000 .
} 
It is therefore clear that the right of the user to benefit from free public services, and the civil servants are held to the strict respect for equity, neutrality which are legally prescribed by law. Since legal texts prohibit the use of informality in all its forms in the administration, failure to comply with these rules exposes crooked officials to prosecution.

On the other hand, empirical facts however demonstrate that, alongside these legal principles, there are informal practices, which depend on a large number of factors, such as the search for personal satisfaction, the pursuit of an interest is well known; the way things actually work are cast aside on the side of the "human factor", the irrational, the emotional, and the personal. Informality experienced a particular development during the 1990s with the drastic drop in the salaries of Cameroonian civil servants who, to compensate for these shortages, rushed to the use of informal practices such as, corruption, clientelism, nepotism, etc.., in most administrative services. The coexistence between formal and informality being a reality in Cameroonian administrative services, therefore this question may be enquired as to know, what are the factors that explain the practice of informality in administrative services and how does it manifest itself? To answer this question, we will first present the factors explaining the practices of informality in administrative services (2), and then, their manifestations (3). The approach adopted for this paper is empirical and is based on observations of facts in the Cameroonian administrative landscape. This approach has enabled us to demonstrate that informality is present and well rooted in some public administrations. The perception and observation of the various administrative services illustrate that some officials act outside the administrative and ethical rules.

\section{Factors Explaining Informality in Public Administrations}

The practice of informality in administrative services is dependent on certain factors such as the difficulties of Africans in general and Cameroonians in particular in mechanically integrating administrative formula imported from Western countries. Also, the social always dominates human relations in African societies; this pushes some individuals to go beyond the rules for the benefit of the affective, without neglecting poverty, which pushes some individuals to favor the practice of informality (corruption), to the detriment of the rules established in the administrative services. In order to better understand these explanatory factors, we will demonstrate that the state crisis constitutes an illustrative element (2.1), without neglecting the socioeconomic pretexts (2.2).

\subsection{The State crisis}

The persistence of informality in administrative practices in a modern country like Cameroon is a response to a vision of the State as an entity under construction. The State under construction can be analyzed through the daily dynamics of the activities of the administration, especially in administrative practices, marked by informality. In practice, the purpose of transgressing the legal order is to circumvent administrative rules. The main focus in this section is, presenting the State crisis as one of the explanatory factors which explain the practice of informality in some of our administrative services (2.1.1.), and neo-patrimonialism as explaining factor will not be left out (2.1.2.). 


\subsubsection{The State Import Crisis}

The origin of informality dates back to the colonial period, the imported State encountered difficulties in taking hold in Africa in general and particularly in Cameroon. The imported State explains, on the one hand, the persistence of the use of informality in some administrative services, since the state registry has not taken a sufficient hold, given that our socio-cultural realities are not identical to that of the western civilizations. On this subject, Foucault (1974: 1591), exposes the relative character of the norms when he declares that: "Everyone also knows that the laws are made by some and imposed on others (...). The law is not made to prevent this or that type of behavior, but to differentiate the ways to circumvent the law itself'. Thus, the structural and functional adaptation of state standards and institutions inherited from colonialism, mechanically stuck in our societies, explains the persistence of informality in our various administrative services. The difficulty in respecting the established norm depends on the application of Western managerial recipes in Africa in general and in Cameroon in particular, hence the assertion of Bertrand Badie and Pierre Birnbaum according to which the State in Africa and Asia would be a "pure imported product". According to Badie (1978: 802), this importation appears, "as an undeniable mark of cultural domination, which would explain why the transposition failed". This is why some authors believe that "in Africa, illegal activities, the interplay between normative rules and practices, the almost infinite web of complicity, are not to be demonstrated, only to be actualized" (Collection Afrique Politique, 2005: 14). This illustration demonstrates the fact that the imported state does not sufficiently espouse our habits and customs, and the consequence is the rejection of the established institutional order. Also, "the conception of power and the attitude of political actors which derive from this paradigm are considered by many authors as a major obstacle to the institutionalization of the state" (Ibid.). The facts sufficiently demonstrate that human relations dominate in administrative services, by favoring informality, Bratton et al., In their writings illustrate that "the real institutions of politics in Africa are informal relations of loyalty and established patronage. between the big men and their personal suite" (Bratton and Van de Walle, 1997: 43-44). It is therefore certain that the "imported State" has manifestly failed, not only in terms of orientation, organization and impulse of standards in our various administrative services, but also in the performance of the function it was assigned above all, namely the building of a powerful "State", via the respect of the formal rules instituted by the law, thus by integrating the various cultural, ethnic and social components.

\subsubsection{The Neo-Patrimonialist Paradigm of Informality}

Neo-patrimonialism is one of the factors that explains the presence of informality in our administrative services in Africa in general and in Cameroon in particular. The expression neopatrimonialism, already used by Eisenstadt, was introduced into French Africanist literature by Jean-François Médard (1991). Neopatrimonialism expresses the tendency towards confusion between the public good and the private good by a manager of public goods. Singularly, according to Jacquemont (2016: 62), "we use the concept of neopatrimonialism to designate the African state social system, extension of the chiefdom system on a national territory: a coalition of interest, made up of self-appointed or elected 
individuals, agree to acquire and maintain their respective privileges". Neopatrimonialism as a practice in our various administrative services is demonstrated by Jean François Médard in his writings on Cameroon, where he reiterates the fact that "the Cameroonian bureaucracy appears to me as a class because it operates for its own account, and as a dominant class because, by the control it exercises over society, it takes the lion's share "(Bayart, 1979: 122). With this illustration, we can understand that the management of Cameroonian administrative services is marked by irregularities linked to the prevalence of informal practices in the management of public goods (prevarication, etc.). Inspired and described by Weber (1971), "traditional" legitimacy, which predates "rational-bureaucratic" legitimacy, like sultanism, is a factor that explains neopatrimonialism, which exhibits characteristics of an arbitrary patrimonial regime with a lack of differentiation between state property (public property) and civil servant property (private property), in other words, there is a certain confusion between public property and private property. Along these lines, "neo-patrimonialism results in personalizing political relations and transforming political resources into economic resources. This notion makes it possible to group together under the same term, related phenomena as patronage, nepotism, (tribalism), (cronyism) and corruption" (Bayart, 1979: 123), practices that we group together under the term of informality. Through the rejection of the established order, the holders of administrative responsibilities have developed illegal practices within the administrative services, namely traffic of influence, which manifests itself in the confusion of the public administration as the private assets by certain officials. In the same manner, apart from the confusion between public and private goods, access to a public office (appointment), automatically develops a source of personal allegiance to the holder of administrative power, hence the phenomenon of "traffic of influence"; because in some services we most often hear the following sentence: "you know who you're dealing with?". Cameroon being a rule of law, it is obvious that formal rules take precedence over informality in the management of public services in our various administrations, thus,

"Neo-patrimonialism does not translate into the absence of legal norms or the reign of tradition, but rather by a conflict of norms in a hybrid state. The result is a private mode of management of official functions, a capture of public rents from a clientele, the primacy of personal loyalties over institutions, a subjugation of the law which does not regulate the behavior of the actors" (Jacquemot, 2016: 62).

It is therefore evident that neo-patrimonialism has an influence on the way individual manage their administrative duties, but this does not mean that the Cameroon's administration functions in anarchy, but that from the above illustration, we realize that there is a conflict between the formal and informality.

\subsection{Socio-economic and Institutional Reasons}

The economic crisis that hit the world in the 1980s spread to over Cameroon. In the 1990s, this crisis prompted the Cameroonian State to lower the salaries of civil servants. This drastic drop in salaries has resulted in the birth of informality (corruption, patronage, traffic of influence) in the various public administrative services, as some officials to supplement their 
ends of the month salaries got involved in this obnoxious practice. In the same way, the cumbersome procedures (administrative bottle necks) and the hyper centralization of administrative services are also features that explain the practice of informality in some of the public administrative services. For a good understanding of this subsection, we are going to present the socioeconomic causes (2.2.1), and also the institutional factors (2.2.2).

\subsubsection{Socioeconomic Pretexts}

In African societies, and particularly in that of Cameroon, individuals are so attached to the community. This is to say that sentiments always surpass the norms and the formal rules established by conventional legal texts. It is common to find that some decisions are always made in favor of a family member or friend even when it is illegal. This type of behavior sufficiently proves that social relations are vectors of informal practices in most of the administrative services. For Blau (1964: 253), "social norms constitute the matrix that forms social relations between groups and individuals. These norms are institutionalized and perpetuated from generation to generation". Their production is generally the result of bargaining between members of a society, but above all the product of dominant power structures. Certain customary rules, certain social norms, leading to forms of mutual aids, cultural values, etc. promote sociability and therefore the emotional takes precedence over the rational. An informant revealed the use of this practice in a company (a parastatal) which recruited accountants, I quote: "the manager recruited two accountants who are members of his family without a press release calling for applications. which indicated that there was a recruitment in his service" (interview carried out on July 31 in Ngaoundéré). It is indisputably an act of informality because normally a statement had to be published to this effect, but as it was to satisfy his family, everything happened out of the respect of formal rules.

Besides, the growing poverty among the Cameroonian population is another cause of the prevalence of informal practices in some administrative services. The economic crisis that hit the world in the 1980s spread to Cameroon with the drastic drop in wages in the 1990s. This had the consequences of avoiding formal rules in almost all administrative services through corruption to compensate the drop in salaries by some civil servants. The economic malaise developed a new way of life which consisted of receiving bribes. Corruption became widespread with police officers who began to extort money from people requesting their services and motorists on the way; a new network called "démarcheurs" in French, an equivalent of middlemen, started prospering in the central services like the Ministry of Finance (MINFI), the Ministry of Public Service and Administrative Reform (MINFOPRA), etc. The term "I earn what" has become widespread in almost all government departments. This economic crisis which continues to shake Cameroon till date has resulted in the circumvention of formal rules, which has led to the practice of informality, which consists of receiving rewards for public services, which are normally free of charge.

\subsubsection{Institutional Factors (Administrative Bottle Necks, Centralization, Etc.)}

The administrative bottle necks in the processing of files is a real problem in the various Cameroonian administrative services. Sometimes, to establish a national identity card, to 
legalize or certify documents, may take days or even months. The complexity of the procedures, linked to complicated administrative formalities, pushes some users to circumvent the rules in order to have an immediate satisfaction. Thus, Michel Crozier (1963: 238) demonstrates that "the rigidity with which the content of tasks is defined, the relationships between the tasks and the network of human relations necessary for their accomplishment, make it difficult for groups to communicate with each other and with the environment". The facts indicate that faced with an excess of regulations, some users are forced to play out of the rules, especially for those who have the financial means to bypass them, or to negotiate arrangements that are supposed to be formal. In town halls, prefectures and ministries, long queues are an obligatory ritual for the population, who increasingly demand less outrageous treatment in order to be served. As Nwabuzor (2005: 126) asserts in his work, he indicates that, "informality is a response to cumbersome controls and an attempt to bypass them". The slowness of procedures remains a phenomenon that plagues relations between citizens and administrations.

Besides, ministries and other public establishments are faced with a set of scourges of laxity (due to the recruitment of incompetent people), lack of information and absenteeism which do not facilitate access to administrative services. And because laxity is present at several levels, a task that could be performed under other skies in a few hours takes months, coupled with a communication deficit as well. For, in an organization and precisely in a bureaucratic system, "information is power, and sometimes, for a brief moment, the essential instrument of power" (Crozier, 1970: 67). The poor flow of information from the bottom to the top of the decision-making sphere can lead to discrepancies and consequently affect the proper functioning of the organization (for example, we have a file registered by the mail service, but it remains in the mail office for various reasons: the file has disappeared or the mail service agent has forgotten to submit it for processing or signature). But administrative bottle necks are not always linked to the laxity of officials in the administrative services. The lack of equipment or the use of old devices are not negligible factors. The lack of computers for typing documents in a court department, for example, can inevitably slow down certain legal procedures. Besides the failure to acquire appropriate equipment, corruption, which plagues the civil service, does not contribute to improving the quality of services in the administration. In Cameroon, police stations, and customs services are places where bribes circulate. A 2015 Transparency International report on corruption in Cameroon revealed that the police are the most corrupt industry in the country.

Furthermore, the concentration of administrative services like the central services of ministries, found exclusively in Yaoundé (the political capital), and even some delegations which are located only in regional capitals, are in some cases the causes of administrative bottle necks. The concentration of important decision-making bodies of the different ministerial departments, solely found in the political capital have increased the complexity and slowness of administrative procedures in the treatment of some administrative files. Indeed, the services provided by the central administration are very slow due to the centralization of decision-making, the ambiguity and the negligence that characterize the execution and diligence of urgent cases. Most of the files are processed and signed only in 
Yaoundé. For example, we have the integration files of Cameroonian civil servants like (teachers, teachers, nurse, etc.), are processed only at the Ministry of Public Service and Administrative Reform. These civil servants encounter the same difficulty with their salary which is processed at the Ministry of Finance still found in the political capital of the country. This practice is dependent on the accumulation of files in these different administrative departments, and the consequence is naturally the slowness in the rapid processing of user files. To speed up the processing of their files, some individuals make use of unconventional practices through bribing in order to be served quickly. It is therefore obvious that these overloads of work in the central services push some officials to act out of the administrative rationality, which consists in sorting the files of users who have cashed in order to satisfy them as a priority. The consequence is the slowness in the execution and the virtual inefficiency of the administrative tasks which some bypass by the use of informality.

\section{The Manifestation of Informality}

Informality manifests itself in the functioning of certain administrative services on Cameroonian territory. On a daily basis, this practice is felt in the non-respect of administrative procedures and deadlines through the strategy of bypassing formal rules. These informalities are manifested in the functioning of administrative services (3.1), and on the other hand in non-compliance with administrative procedures and deadlines (3.2).

\subsection{In the Operation of Administrative Services}

The operation of administrative services is undermined by the practices of informality which hamper the performance of the administration. Informality practices manifest themselves through the network of human relations. The coinage of services is also reflected through mafia organizations such as corruption and patronage. In practice, administrations operate in informality (3.1.1), as well as bypassing administrative rules through corruption "middlemen" (3.1.2).

\subsubsection{Informality in Public Administrations}

The informal running of some of our administrations is manifested by the fact that some civil servants confuse the administration to their personal assets. Administrative management is carried out illegally, out of the administrative rules prescribed by Cameroonian law in matters of public services. This type of operation is explained by the neo-patrimonialist paradigm where state personnel confuse either administration or government assets with their own assets. Various testimonies tell us that in certain public services like certain delegations of departments or regional delegations, town halls, police services, customs services, justice services, ministries etc., are administrative departments where informality often prevails. A user met in the premises of the council of Maroua 1 (interview of September 15, 2020 in Maroua) stated that, he has been walking for months to establish a birth certificate for his child, unfortunately without a fruitful result. According to our investigations, we noted that some agents of this municipality did not have the administrative training required for work in the civil status service, given that they are closely related to the various municipal councilors, their recruitments are most often done informally without first of all, respecting the eligibility 
conditions. Obtaining this document is therefore done informality, because some users make use of their informal "networks" to obtain it by all possible means. Likewise, informality is rampant in some police departments where the commissioner and his collaborators believe they have the right to treat people as they want. An investigation in the North Region disclosed the fact that in some police stations, citizens are kept in custody for months without sufficient reason. A young man from Pitoa(a locality found in the North Region), disclosed to us that he was held in police custody for 23 days (for overloading on his motor bike), while his parents were looking for money to pay the police commissioner for his release (Interview made in Pitoa on the $22^{\text {nd }}$ of August 2020). Informality is demonstrated here by the non-compliance with the regular period of custody which is 48 hours renewable only once. As a result, the commissioner confuses the police station as his legacy and he manages the various disputes between the populations as he feels fit, without taking into account the ethical and administrative rules. In the same way, some ministries have recently been transformed into a nest of informality. This manifested by the fact that most agents are negligent and lack professionalism. An individual can spend months or even years just to sign an administrative document. An interview with a teacher (contracted) from the Ministry of Basic Education tells us I quote:

"I am from the first batch of teachers contracted in 2005, I submitted my integration file to the Ministry of Public Service since February 2019, without a fit back. I went to that ministry in October 2019, a lady made me understand that my file is indeed recorded, but the physical file has disappeared and that I have to compile another file and hand it over to her personally" (interview done in Maroua on September 17, 2020).

This testimony demonstrations that informality reigns in this ministry because if a file cannot be processed when it follows the normal circuit, this simply means that the formal has to give way to the illegal. As well, some transport delegations have also turned into an environment for issuing driving licenses illegally. Informality results in the issuance of driving licenses to individuals who do not meet the criteria required in obtaining this document. Having a relative or a friend in the department of the Ministry of Transport is advantageous for those willing to obtain this document unlawfully, the consequence is that, an individual can obtain a driving license even if he / she does not know how to drive or has never set foot in a Driving school (compulsory condition to obtain a driving license). Many drivers across the country disclosed to me that, they got their driving licenses without going through a driving school and also, some having these driving licenses do not even know how to drive. "If everyone indeed understands what the expression "to play its relations" means, it will be a question here of a more particular practice, consisting for an elected official "to support requests for interventions which are addressed to him by individuals" (Bour, 2018: 9).

Furthermore, through the rejection of institutional order, informal practices such as traffic of influence in administrative services becomes the rule. Certain agents or heads of administrative services use their influential positions to influence their collaborators to render services to them out of compliance with the administrative rules established by the law which governs procedures in the administrative services. Very present in the doctrines of the new 
administration, even of "public management", the process of informal actions" (Gaudemet, 1994: 647). According to several informants, certain senior officials (directors, ministers, and their collaborators) regularly use their influential positions to provide undeserved advantages to people who seek their help. With their position of power, a simple phone call can make an administrative competitive entrance examination in, (Higher Teacher Training College, National School of Administration and Magistracy (ENAM), Institute of International Relations of Cameroon (IRIC)), to an individual who has a close relation with a senior official of the republic via traffic of influence. With the traffic of influence, it appears that those who have administrative or political power can influence illegal decisions in favor of an individual. Observation of the facts in the various administrative services, proved that rationality is often been flouted in favor of informality by some rogue officials.

\subsubsection{Bypassing Administrative Rules Through Corruption}

Informality in the Cameroonian administration is also reflected in the form of exchange in kind or money for administrative services, normally free of charge. The users who engage in these arrangements are most often in an illegal position. Using corruption allows them to bypass legal administrative barriers. Today, many of the illegal services are obtained through haggling of all kinds, ranging from the simple provision of services to buying competitive recruitment examinations illegally. Impunity, laxity and a lack of professional ethics have made unsavory activities flourish in some administrations. Neopatrimonialism continues to prevail in our administrations because some officials still tend to confuse the administration with their private assets. The management of administrative services is carried out illegally without respecting the standards established by law. Some agents or officials charge most users for services that are supposed to be free. This act of informality has been established as a standard in most public services in Cameroon where an individual can illegally or legally obtain a favorable result to his request. Unlawfully, an individual without a right to a service can obtain it through bribery. However, legally, an individual supposed to obtain a free service under the pressure of traffic of influence is forced to pay a sum of money by the official either to speed up the processing of his case or to simply be served. Observation of empirical facts shows us that corruption is the consequence of informality, because it is reprimanded by law in the Cameroonian context.

Besides, bypassing administrative standards with the aim of favoring a relative or an acquaintance via corruption constitutes a violation of the law in Cameroon. It is even qualified as a "pathological" phenomenon (Durkheim 1895: 47-75), since it acts on the fringes of legality. Article 134 of the Cameroonian penal code punishes any public service official guilty of corruption. Despite the repression of this heinous act, corruption is becoming more and more widespread in certain administrative services and even among certain local elected officials, who solicit donations in kind or in cash in order to use or abuse their power to obtain undeserved advantages to or a favorable opinion for a third party. As a result, adherence to the norms works when it pays, as all the time we hear some officials say "what do I earn", whereas he is paid by the government to provide this service users. The administrative services thus find themselves operating on the margins of the principles of ethics and integrity prescribed by the code of ethics. In fact, "holders of a piece of public 
power are tempted to abuse their powers to the detriment of companies or the state" (Titi Nwel, 1999: 43).

Also, with corruption, unfair competition thrives in most cases, since the corrupter finds themselves in a favorable position (purchase of competition), to the detriment of those who rely on their intellectual skills. This practice of informality manifested itself, "initially when entering the National Police School, said one interlocutor. To enter, you must either pay a large sum of money or be sponsored" (Titi Nwel, 1999: 53). Access to certain National schools, such as the National School of Administration and Magistracy, is for some through corruption. A situation that attracted the attention of the Cameroonian public during the 2017 edition was, when, late Millsaints-Claude Ndjomo, was declared the best candidate of, (cycle A, section of social affairs administration), even though he died long before the conduct of the interview that counts for the overall results of this competitive examination; still at the National School of Administration and Magistracy, in the same edition of November 2017, two results were published for the same session; the first published in the 5 pm radio news, canceled and a second list published in the 8 pm radio news, the same day. A scandal that led to the dismiss of the Minister of the Civil Service and Administrative Reform at the time, shortly after the publication of these results. This corruption also plagues the Ministry of Finance (MINFI); here, its manifestation, "consists in greasing the paws of the agents of this ministry so that a file of advancement, integration, etc. ... is treated with diligence" (Titi Nwel, 1999: 51). Subsequently, at the ministry of Finance, "lately, the race of middlemen commonly known in French as "démarcheurs" (Ibid.) started flourishing. The result is the loss of confidence in institutions and public authorities and in the same way, an erosion of the rule of law itself.

Furthermore, in tax services, informality manifests itself in the use of ICT (Information and Communication Technology) tools to downgrade or upgrade the corporate tax system. According to some informants, who are businessmen themselves, an entrepreneur can keep his business at the lower tax level if he has an acquaintance or friend who works in the tax office. In the name of family or friendship, a tax officer can do a favor to his relatives in order to prevent them from going to the next level that is, from paying lower tax regime to higher tax regime. Others pay large sums of money to maintain a lower tax regime tax as well. The consequence is the overclassification of taxes for businessmen who do not have somebody or a friend at the tax department or those who refuse to pay bribes, and a downgrade for those who have relatives or friends in these departments or for those who have paid bribes. Several companies today having achieved colossal turnover, followed by an increase in their size, are still classified under the low tax regime instead of moving to the patent regime. It is therefore evident that the economic health of the country is damaged when we witness the informal management of tax regimes.

Again, in the court services, the deficit or lack of working materials has given rise to a new practice among court clerks, which consists of asking users to pay for "typing fees". From field investigation, we came across people who were victims of this" typing fees", and one of the confide to me that I quote: 
I went the court to apply for an appeal, but the clerk asked me to pay 1000 frs CFA, as typing fees. When I refused, the clerk simply told me that the computer he is using is his personal computer that he bought with his own means and that if I was not willing to pay, I can go and type my document somewhere else. Finally, I was obliged to pay the fees. (Interview of $22^{\text {nd }}$ July 2020 in Ngaoudéré-Cameroon)

The main factor behind this practice of informality in the court services is the poor management of public resources meant for the purchase and the modernization of working equipment's. The clerks who are confronted with the various users who request the typing of their official documents, purchase their own working materials amongst which we computers and they charge this service to users for services which are supposed to obtain free of charge, if working materials were available.

Still, in our health centers or hospitals, informality is manifested here in the form of illicit sale of medicines. This time around, a network of illicit sales of medicines by health workers who purchase these medications in black markets has been developed. A talk with some patients enabled us to investigate on this illicit sale of medicines. A patient made in a health center in Maroua town confide to me, I quote: I buy some the medicines prescribed to me from the nurses who propose and sale them to me at prices which are much cheaper than the one bought in the health center's pharmacy. (interview made on the $16^{\text {th }}$ of September 2020 in Maroua). These drugs are retailed to patients at unbeatable prices by health workers in certain hospitals and health centers. In the same vein, some drug depots have turned into places where drugs of dubious origin can be used in conjunction with the staff and managers of these depots. Bribes (sums of money or gifts in kind) are also paid to health auxiliaries in order to meet easily or quickly with doctors, who are most often inaccessible due to the excessive number of patients to attain to. The option to meet the doctor swiftly in case of emergency remains the use of networks (informality) in order to be received and treated quickly. We have another aspect of unconventional practices in the health sector which consists of diverting patients to private hospitals. This way of doing is rampant in towns like Yaounde where I made a patient who reveal to me, I quote: "the Doctor gave an appointment in a private clinic, at $4 \mathrm{pm}$ to better attain to my health problem because he lacks the appropriate material in the public hospital where he is now". The consequence is that most patients are diverted, with a scheduled or an appointment to private clinics where he/she will be received as soon as possible. Thus, although workers of public health structures and being paid by the State, some doctors and nurses constitute a large private clientele.

Moreover, clientelism, another form of informality prevails especially during electoral periods, this is done via the exchange of favors for electoral votes (Delia and Mény, 1995: 44). Jean-François Médard (1976: 117) supports that: "the resources exchanged can be of extremely diverse nature: economic, political, religious, psychological, military, judicial, administrative, educational (...) all aspects of life are concerned". It is a practice of exchanging services and goods out of formal rules. For Médard (1976: 122), "in the clientelist strategy, everyone, boss as client, seeks in the exchange to enhance the value and monetize his resources as much as possible". Unlike corruption, clientelism is based on an 
exchange between elected officials and voters. Clientelism as corruption-social exchange, elected officials provide a number of goods and services in exchange for political support. This is a more or less tacit exchange since elected officials cannot control the votes of those to whom they have rendered a service. However, it is most often a relationship of mutual trust that can develop over the long term. This practice is most often done during election campaigns where the client (voters), based on his vote or political support, ensures the improvement of his social situation (promise of employment, etc.). With the use of informality, there are situations where, "in certain cases, state interventionism has even led to a systematization of clientelary practices, to the point of having made it one of the main foundations of partisan mobilization" (Briquet and Sawicki, 1998: 3). According to our sources of information, the involvement of Cameroonian civil administrators in issues related to electoral campaigns consists in influencing traditional leaders so that they can convince or force their subjects to vote for a particular political party.

\subsection{In the Administrative Procedure}

Informality is also felt most often in the administrative procedure. In the various public services, there are procedures and deadlines for the processing of certain administrative files, but the informal practices in certain administrative services make it possible to bypass these procedures as well as the deadlines. The same situation is experienced in public procurement with the phenomenon of favoritism. In this subsection, we are going to demonstrate the practice of informality in administrative services through non-compliance with administrative procedures and deadlines (3.2.1), and favoritism in the award of public procurement (3.2.2).

\subsubsection{Failure to Comply with Administrative Procedures and Deadlines}

In our various administrative services, there are administrative procedures established by law and also deadlines to be observed for a certain number of cases to be processed. But it happens that in practice, some officials and some users of administrative services circumvent these procedures and deadlines instituted by administrative rules in favor of informal practices to speed up the processing of their files. This approach is a prove that informality prevails and undermines the proper functioning of administrative services in our country. The following examples are illustrative of informality in the department of the Ministry of Justice or court services:

Besides, in the court department, as long as you know someone in a service, you can get an "engrossment" $" 3$ of the judgment of inheritance without presenting the report of the family councils consisting of at least seven people, members of the family of the deceased or people who know the family well. According to an informant, some people pass through the cracks of the procedures and deadlines known to establish the "engrossment", individuals are made establish this document illegally by bypassing the deadlines and administrative procedures: namely the judgment of heredity, which is followed by the establishment of a certificate of non-appeal produced one month after this judgment ${ }^{4}$. A court clerk disclosed to me that some court cases are processed without respecting some legal datelines as he said, I quote "many

\footnotetext{
${ }^{3}$ It is an exact copy of an official document or a judgment in the form of enforceability

${ }^{4}$ Interview made with an informant in Ngaoundéré (Adamawa Region of Cameroon) on the $14^{\text {th }}$ July 2020.
} 
people get their "engrossment", without presenting the family council file that is supposed to be signed by the divisional officer, and also without the heredity judgment"(interview made in Ngaoundéré on the $14^{\text {th }}$ of July 2020). In some courthouses, these informal practices are rampant and as long as the person concerned knows someone in one of the court services, he / she can have this document (the "engrossment"), in a day instead of waiting for at least a month as the law prescribes. According to several sources (some court clerks), circumvention of administrative procedures and deadlines for the establishment of legal documents is constantly violated at the courthouse in the city of Ngaoundére and in other regions of the country. This demonstrates the prevalence of the use of informality practices in Cameroonian court services.

Furthermore, failure to comply with administrative procedures and deadlines is often practiced in certain councils also, with marriages that take place without the publication of wedding banners, and civil status documents that are signed in the homes of certain mayors. According to our informants, the establishment of birth certificates for people whose birth declaration was done after the legal date line which is 90 days for the establishment of their certificate is done informally. The informality noticed here is the fact that, birth certificates are produced to these children or elder people without the respect of legal rules, because normally, a parent who fail to comply with the birth declaration date line will have to go to court for an auxiliary judgement with witnesses that will confirm his/her parenthood of the child. This informal practice is rampant in the municipality of the Ngaoundéré III district. According to an informant, "those concerned only present themselves with information's concerning them on a piece of paper and the former mayor (2013-2020), established and signed these certificates without respecting the procedures provided by law regarding the establishment of birth certificates for people who have exceed the date line of birth declaration"(interview made in Ngaoundéré on the $25^{\text {th }}$ of July 2020). Another informant confides to me that I quote "my marriage certificate was signed at the $1^{\text {st }}$ deputy mayor's home without the presence of my wife or her relatives. I presented myself with a friend and the marriage was signed" (interview made on the $15^{\text {th }}$ of July 2020). These types of practices sufficiently prove that informality is established as a rule in the management of some cases related to the establishment of civil status documents in certain district councils of Cameroon.

\subsubsection{Failure to Comply with Public Procurement Standards}

The award of public contracts in our various administrative services is one of the activities whose execution is marked by irregularities which are the non-respect of the rules of fairness and transparency in the award and execution of public contracts. Here, informality takes the form of nepotism and corruption. Apart from the volume of transactions and retro commissions, the complexity of the process is intensified by the close interaction between public officials, companies, and the multitude of stakeholders, "middlemen".

Firstly, In the context of public procurement, informality is translated into nepotism, which consists of obtaining or attempting to procure for others an unjustified advantage by an act contrary to the legislative and regulatory provisions governing public contracts and the delegation of public service. With regard to the transgression, we have nepotism which is 
characterized by the execution, in full knowledge of the facts, of an act contrary to the regulatory provisions aimed at guaranteeing freedom of access and obscuring the equality of candidates in public procurement. When the unlawful intention manifests itself in the irregularity of the procedure by circumventing the rules of the public procurement code in all conscience, we are here faced with a practice of informality.

Besides, observation on the ground demonstrates that public procurements are the privileged theater of non-compliance with the legal standards that govern the award of public contracts. Informality takes the form of bribes, which involve agents with significant decision-making power in public administration or in decentralized local communities. According to Transparency International (2011), bribes are "seen as the most common form of corruption, an offer of money, goods or services aimed at obtaining an advantage that the recipient has no legal right to grant" (Heggstad and Froystad, 2014: 8). In day-to-day practice, bidders for construction, equipment or material procurement, etc., influence the control committees simply by paying bribes to the committee members to approve their contract, or speed up the processing of their request. CEOs or managers and / or contractors most often pay a regulatory body or inspection service to turn a blind eye to lapses in complying with current regulations. A contractor disclose to me I quote: "a contract was withdrawn from me because I refused to bribed the committee involved in granting me the contract, and they gave as reasons that I did not fulfill the requirements to take on that contract" (interview made on the $20^{\text {th }}$ of August 2020 in Garoua). This is a clear evidence that informal practices like bribery and corruption are rampant in public procurements.

As a matter of fact, the violation of the fundamental principles of public procurement involves the "legal" circumvention of regulations. According to Article .2.- The rules set by this code are based on the principles of freedom of access to public procurement, equal treatment of candidates and transparency of procedures ${ }^{5}$. From this clause of public procurement, it is clear that the law prescribes equity and transparency of procedures, but unfortunately, empirical evidences display the non-respect of equal treatment, freedom of access and transparency of procedures, the impartiality of competition which allows public procurement at the best value for money, is a mechanism used to favor certain providers and to push the contract out of the established rules. In this type of selfish interest game, the rules of the game are such that qualified bidders are excluded. For Article .7.- 1 public contracts are awarded after competition between potential co-contractors of the Administration on call for tenders ${ }^{6}$. To reduce the number of potential contractors and eliminate competition, several strategies are implemented. They have as a common denominator the manipulation of information. The process developed in most cases is opacity in the publication and dissemination of the call for tenders via the various media channels, namely broadcasting, the written press, the information services of the chamber of commerce. The confidentiality of the information of the various calls for tenders excludes competition and therefore the contract is awarded to a family member or friend in informality since the rules of the game were not respected. In the same logic, another method lies in the implementation of

\footnotetext{
${ }^{5}$ Code des marchés publics, Décret n²004/275 du 24 septembre 2004

${ }^{6}$ Code des marchés publics., Op cit.
} 
intimidating practices which consist in making it difficult to access regularly published information, or pushing interested entrepreneurs to withdraw. This is the case, for example, with the excessive reduction in the response time of potential bidders. Everything takes place within and out of the established rules, passing through informal practices to circumvent the law that governs the award of public contracts.

\section{Conclusion}

Ultimately, this work, has as objective to question the factors that explains the use of informality in the Cameroon's public administration and also to demonstrate with concrete facts its manifestation in our various administrative services. According to empirical evidences, it emerges that "in many countries of Africa, Latin America and Asia, informality is the norm, because it is a dominant socio-economic reality" (Bennafla, 2015: 2). Observation of the facts demonstrates that informality in our various administrative services, reveals the existence of a real mafia network, in which corruption, favoritism, abuse of public goods is inextricably entangled, fraud, falsification of accounting, forgery and use of false documents, unconventional practices that are becoming the norm. Paraphrasing Professor Hubert Mono Ndjana (2010), who basically says that in Cameroon we have normalized the gap and sidelined the norm, is once again the evidence that, the norm is constantly sidelined in favor of informality. The facts display that the State in Africa operates according to socio-cultural realities. Thus, for (Médard, 2000: 85) "if we consider the case of the neo-patrimonial State in Africa, the corruption which characterizes it can only be understood globally from the mode of operation specific to such a type of State". That said, we can conclude that the cohabitation between formal practices and informality rests in the functioning of African societies in general and Cameroonian in particular, which is based more on the affective and the social than on the respect of the formal rules imported with managerial recipes specific to other civilizations. In the same logic, since the end of the 1990s with the devaluation and the drastic cut in the salaries of civil servants, the growing poverty linked to the economic crisis coupled with the lack of ethics on the part of some Cameroonian civil servants, we have witnessed a trivialization of the instituted order, most often, due to impunity, administrative tolerance and laissez-faire, thus promoting informality. However, these practices weaken, equity, transparency, accountability and legitimacy by undermining conventional administrative standards. The persistence of informality despite the efforts made by the Cameroonian State to eradicate these illegal practices in the various administrative services are not yielding the awaited result.

Besides, to overcome these unlawful practices, it is advisable for the government to keenly examine the factors that developed informality in the different administrative services of the country. The development of a code of conduct with strict respect of legality will be a possible solution to eradicate informality. In the same manner, effective decentralization of some ministries will reduce work load of civil servants working in the different ministries found only in Yaoundé. This will avoid stocks of files to be processed and the possible consequence will be the complete eradication of middlemen "démarcheurs", who have constituted themselves as facilitators of files processing in exchange of financial benefits. Also, administrative bottle necks due to the complexification of administrative procedures are 


\section{Macrothink}

Journal of Public Administration and Governance ISSN 2161-7104 2021, Vol. 11, No. 1

features that boosts informality, because most individuals will try to bypass these procedures by using informal ways to prompt the treatment of his/her files. This can be reduced by simplifying these procedures, by decentralizing administrative responsibilities. Again, the poor civil servants who make use of informality to round up his end of month expenses, can be given a better payment treatment to enable them have an acceptable living standard and consequently, bad practices linked to informality may be reduced.

\section{References}

Anderson, P. (1978). L'État absolutiste. Ses origines et ses voies, Paris, La Découverte.

Badie, B., \& Birnbaum, P. (1978). Sociologie de l'État. Paris, Grasset.

Badie, B. (1993). État importé occidentalisation de l'ordre politique. Cases, Politique étrangère, 3(58), 802-803.

Bayart, J.-F. (1979). L'État au Cameroun, Paris, Presses de la Fondation nationale des sciences Politiques.

Bennafla, K. (2015). Informalité. Notion à la une de Géoconfluences, [En ligne : http://geoconfluences.ens-lyon.fr/informations-scientifiques/a-la-une/notion-a-la-une/notion-a -la-une-informalite/accessed September 19, 2020].

Blau, P. M. (1964). Exchange and power in social life, New York, John Wiley and Sons.

Blau, P. M., \& Scott, W. R. (1962). Formal organizations: A comparative approach. San Francisco: Chandler

Bour, J. (2018). Clientélisme politique et recommandation, Rennes, Presses universitaires de Rennes.

Bratton, M., \& Walle, N. de V. (1997). Democratic Experiment in Africa. Regimes Transitionsin Comparative Perspective, Cambridge, Cambridge University Press. https://doi.org/10.1017/CBO9781139174657

Briquet, J.-L., \& Sawicki, F. (1998). Le clientélisme politique dans les sociétés contemporaines », Paris, Presses Universitaires de France.

Collection Afrique Politique. (2005). Gouverner les sociétés africaines : acteurs et institutions, Paris, Karthala.

Crozier, M. (1963). Le Phénomène bureaucratique, Paris, Seuil.

Crozier, M. (1970). La Société bloquée, Paris, Seuil.

Dalton, M. (1959). Men who manage, New York, John Wiley \& Sons.

Delia, D. P., \& Mény, Y. (dir.). (1995). Démocratie et corruption en Europe, Paris, La Découverte.

Derumez. (2017). Les grands auteurs en Management, Caen, EMS. 
Eisenstadt, S. N. (1973). Tradition, Change and Modernity, New York, Willey.

Foucault, M. (1974). Dits et écrits I, «Sur la sellette », Paris, Gallimard.

Gaudemet, Y. (1994). Les actions administratives informelles. Revue internationale de droit comparé, 46(2), 645-654. https://doi.org/10.3406/ridc.1994.4894

Geoffroy, F. (2014). Penser l'informel. Non-concept ou méta-concept pour le management ?, France, Université de Picardie Jules Verne. pp. 1-17.

Heggstad, K. K., \& Froystad, M. (2011). Les fondements de l'intégrité dans la passation des Marchés. Bergen, Chr. Michelsen Institute, 16, 1-47.

Jacquemont, P. (2016). L'Afrique des possibles : les défis de l'émergence, Paris, Karthala.

Labro, C. (dir.). (2010). Dictionnaire Hachette, Paris, CEDEX.

Lautier, B. C. de M., \& Morice, A. (1991). L'État et l'informel, Paris, L'Harmattan.

Litterer, J. A. (1963). Organizations: Structure and behavior, New York, John Wiley \& Sons.

Médard, J.-F. (1976). Le rapport de clientèle, du phénomène social à l'analyse politique. Revue Française de Science Politique, 26, 103-131. https://doi.org/10.3406/rfsp.1976.393655

Médard, J.-F. (1991). L'État néo-patrimonial en Afrique noire, Paris, Karthala.

Médard, J.-F. (2000). Clientélisme politique et corruption. Tiers-Monde, 41(161), 75-87. https://doi.org/10.3406/tiers.2000.1051

Nwabuzor, A. (2005). Corruption and Development: New Initiatives in Economic Openness and Strengthened Rule of Law. Journal of Business Ethics, 59(1- 2), 121-138. https://doi.org/10.1007/s10551-005-3402-3

Schein, E. H. (2017). La culture organisationnelle. Charreire, S., Les Grands Auteurs en Management, Caen, EMS, 453-471. https://doi.org/10.3917/ems.charr.2017.01.0453

Titi Nwel, P. (1999). De la corruption au Cameroun, Yaoundé, GERDDES-Cameroon, Friedrich-Ebert-Stiftung Cameroun.

Van Tatenhove, J., Mak, J., \& Liefferink, D. (2006). "The inter-play between formal and informal", Perspectives on European Politics and Society, 7(1), 8-24. https://doi.org/10.1080/15705850600839470

Wallerstein. (1974). The Modern World System. Capitalist Agriculture and the Origins of the European World Economy in the Sixteenth Century, New York, Academic Press.

Weber, M. (1971). Wisdom and science in sociology. Schneider, L., The sociological quarterly, 12(4), 462-472. https://doi.org/10.1111/j.1533-8525.1971.tb01375.x 


\section{Copyright Disclaimer}

Copyright for this article is retained by the author(s), with first publication rights granted to the journal.

This is an open-access article distributed under the terms and conditions of the Creative Commons Attribution license (http://creativecommons.org/licenses/by/4.0/). 